RE: Manuscript \# JELECHEM-D-15-00430R1

\title{
The Observation of Ion-Pairing Effect based on Substituent Effect of Ferrocene Derivatives
}

Yujie Shi, Liu Fang, Xuan Li, Liangti Qu, Huibo Shao*

Key Laboratory of Cluster Science (Ministry of Education of China) and Beijing Key Laboratory of Photoelectronic/Electrophotonic Conversion Materials, School of Chemistry, Beijing Institute of Technology, Beijing 100081, P. R. China

*Corresponding author: Tel.: +86 1068912667 ; Fax: +86 1068912631

E-mail addresses: $\underline{\text { hbs@bit.edu.cn }}$

\begin{abstract}
The ion-pairing effect was investigated based on the substituent effect of ferrocene (Fc) derivatives using cyclic voltammetry. It was shown that the presence of ion-pairing strongly affected the electrochemical redox behavior in the organic solvent. The formal redox potential $\left(E^{0^{\prime}}\right.$, the average of anodic and cathodic peak potential) shifted negatively with the increasing ion-pairing effect. That was because the formation of ion pair $\left(\mathrm{Fc}^{+} \cdot \mathrm{ClO}_{4}^{-}\right)$was beneficial to equilibrium shift from $\mathrm{Fc}$ to $\mathrm{Fc}^{+}$in thermodynamics. In this work, electron-donating and electron-withdrawing substituents of ferrocene derivatives were employed for deep study of ion-pairing effect, respectively. It is confirmed that both ion-pairing effect and electron-donating substituent effect facilitated the negative shift of $E^{0^{\prime}}$ for ferrocene derivatives, showing the positive cooperativity. While the electron-withdrawing substituent effect resulted in the positive shift of $E^{0^{\prime}}$ for ferrocene derivatives and was unfavourable for
\end{abstract}


the oxidation of $\mathrm{Fc}$ derivatives, reflecting the negative cooperativity with ion-pairing effect. In addition, the reversal phenomenon of weak electron-withdrawing substituent was revealed when the ion-pairing effect was stronger than the electron-withdrawing substituent effect, indicating the ion-pairing function has a significant effect on electrochemical behavior of ferrocene derivatives.

Keywords: Ferrocene derivatives; Substituent effect; Ion-pairing effect; Positive/Negative cooperativity; Reversal phenomenon

\section{Introduction}

Ferrocene $(\mathrm{Fc})$ and its derivatives attract extensive research interest largely due to their inherent reversible redox property, excellent thermal stability and good solubility in non-aqueous solvent. Many ferrocene derivatives have been synthesized and studied [1-5] for diverse applications in functional material science [6-9], biological chemistry and electrochemistry [10-13]. Among them, one of the most noticeable features is the favorable redox properties of Fc, which makes it a popular marker in electrochemical biosensors [14-16].

The oxidation of neutral $\mathrm{Fc}$ generates the oxidized ferrocenium cation $\left(\mathrm{Fc}^{+}\right)$, which forms ion-pairing with anions in solution. Thus, the redox reaction of $\mathrm{Fc}$ is influenced by the presence of anions in the medium [17-21]. The ability to form ion pairs with $\mathrm{Fc}^{+}$varies for the different type and concentration of anions. Consequently, the voltammetric behavior (including formal redox potential and peak shapes) of Fc is 
strongly influenced by ion-pairing effect. There are a few reports in the literature that provides considerable insight into the fundamentally important aspect for ion-pairing effect on electrochemical behavior of ferrocene derivatives. The effects of the nature and concentration of counter anions in aqueous media on cyclic voltammetry $(\mathrm{CV})$ was investigated in a polymer film by Inzelt and Szabo [20]. Subsequently, the ion-pairing effect on the redox behavior of $\mathrm{Fc}$ was studied in self-assembled monolayers (SAMs) [22,23]. Uosaki and co-workers performed CV of the ferrocenyl SAMs in various concentrations of $\mathrm{HClO}_{4}$ solutions and proposed that the shape and position of the redox peaks were strongly affected by the anion [22]. In a later research, Kondo et al. studied the ion-pair formation between $\mathrm{Fc}^{+}$and different anions in the aqueous and dichloromethane solutions and discovered an opposite tendency in the two phases [23]. In our previous work done by Xiang [24-26], the redox behavior and ion-pairing thermodynamics of ferrocenyl compounds in the organic phase have been studied. It showed that the presence of supporting electrolytes in the organic phase complicated their redox behavior. Although it is interesting and important to investigate the ion-pairing effect of ferrocene derivatives in organic solvents for fundamental science and industrial applications, few reports are available on the ion-pairing effect based on substituent effect of ferrocene derivatives.

In this work, we have studied the ion-pairing effect based on the electron-donating and electron-withdrawing substituents of ferrocene derivatives, respectively. It presents both the positive and negative cooperativity between substituent effect and ion-pairing effect. Reversal phenomenon of weak 
electron-withdrawing substituent on redox potentials is confirmed. The work is conducive to achieve a better understanding for the ion-pairing effect on electrochemical behavior of ferrocenyl derivatives.

\section{Experimental}

\subsection{Chemical reagents}

Ferrocene $(\mathrm{Fc})$, aminoferrocene (described as $\mathrm{Fc}-\mathrm{NH}_{2}$ ), ferrocenylmethanol (described as $\mathrm{Fc}-\mathrm{CH}_{2} \mathrm{OH}$ ), bromoferrocene (described as $\mathrm{Fc}-\mathrm{Br}$ ), ferrocenecarboxaldehyde (described as Fc-CHO), vinyl ferrocene (described as $\mathrm{Fc}-\mathrm{CH}=\mathrm{CH}_{2}$ ), 1,2-dichloroethane (DCE), tetraethylammonium perchlorate (TEAP) and 1-ethyl-3-methylimidazolium hexafluorophosphate $\left(\left[\mathrm{Emim} \mathrm{PF}_{6}\right)\right.$ were purchased from a chemical supplier (J\&K Scientific Co., Ltd., Beijing, China). All chemicals were of analytical grade or better and used as received without further purification. The used ultrapure water with $18.2 \mathrm{M} \Omega \cdot \mathrm{cm}$ was from a Milli-Q filter (Research UV, Hetai Instrument Co. Ltd., Shanghai, China).

\subsection{Apparatus and Procedure}

Electrochemical measurements were performed in a conventional three-electrode cell. Gold $(\mathrm{Au})$ disk as working electrode (3 $\mathrm{mm}$ in diameter), platinum wire as counter electrode and $\mathrm{Ag} \mid \mathrm{Ag}^{+}\left(0.01 \mathrm{M} \mathrm{AgNO}\right.$ in $\mathrm{DCE}$, saturated [Emim] $\left.\mathrm{PF}_{6}\right)$ as reference electrode were purchased from $\mathrm{CH}$ Instrument (Chenhua Instrument Co., Ltd., Shanghai, China). Before measurement, the working electrode was mechanically 
polished with 1.0, 0.3 and $0.05 \mu \mathrm{m}$ alumina slurries in particle size successively. After polishing, the working electrode was sonicated for $5 \mathrm{~min}$ in a $1: 1 \mathrm{v} / \mathrm{v}$ mixture of water and ethanol. Then the working electrode was potentiostatically scanned (100 $\left.\mathrm{mV} \mathrm{s}^{-1}\right)$ for 30 cycles in $1.0 \mathrm{M}$ sulfuric acid solution with the potential window from -0.2 to 1.6 V (vs. SCE) and dried in the nitrogen atmosphere for $10 \mathrm{~min} . \mathrm{Fc}$ and its ferrocene derivatives were dissolved in DCE containing $0.1 \mathrm{M}\left[\mathrm{Emim}^{\mathrm{P}} \mathrm{PF}_{6}\right.$, respectively. All solutions were bubbled with nitrogen for $10 \mathrm{~min}$. CV was performed using a potentiostat (CHI 920C, Chenhua Instrument Co. Ltd., Shanghai, China). All potentials were reported against the $\mathrm{Ag} \mid \mathrm{Ag}^{+}$.

\section{Result and Discussion}

\subsection{Ion-pairing effect based on electron-donating substituent}

In this study, aminoferrocene (described as $\mathrm{Fc}-\mathrm{NH}_{2}$ ) and ferrocenylmethanol (described as $\mathrm{Fc}-\mathrm{CH}_{2} \mathrm{OH}$ ) were selected as strong and weak electron-donating substituent for investigating ion-pairing effect, respectively. In our experiments, the formal redox potential $\left(E^{0^{\prime}}\right.$, the average of anodic and cathodic peak potential) of $1 \mathrm{mM} \mathrm{Fc}$ (without $\mathrm{ClO}_{4}{ }^{-}$) was used as a reference, aiming to compare the shift of $E^{0^{\prime}}$ for ferrocene derivatives (absence or presence of $\mathrm{ClO}_{4}{ }^{-}$in solution). $0.1 \mathrm{M}$ [Emim] $\mathrm{PF}_{6}$ was used as the supporting electrolyte.

As shown in Fig. 1A and 1B, pairs of well-shaped redox peaks of $\mathrm{Fc}^{+} / \mathrm{Fc}$ were observed at the Au electrode. The anodic peak currents $\left(I_{\mathrm{pa}}\right)$ and cathodic peak currents $\left(I_{\mathrm{pc}}\right)$ were nearly identical for each voltammogram, indicating that 
oxidation-reduction reaction was chemically reversible.

In this work, the TEAP was added into the systems for studying the ion-pairing effect based on electron-donating substituent of ferrocene derivatives. Although the $\mathrm{PF}_{6}^{-}$anion had similar ion-pairing ability as $\mathrm{ClO}_{4}^{-}{ }^{-}[21]$ as supporting electrolyte, we fixed the concentration of $\mathrm{PF}_{6}^{-}(0.1 \mathrm{M})$ throughout the experiment by control over the presence or absence of $\mathrm{ClO}_{4}^{-}$and different substituents. Hence, ion-pairing effect caused by $\mathrm{Fc}^{+} \cdot \mathrm{ClO}_{4}{ }^{-}$is the main influence factors. The redox reaction should be expressed as follows:

$\mathrm{Fc}+\mathrm{ClO}_{4}^{-} \rightleftharpoons \mathrm{Fc}^{+} \cdot \mathrm{ClO}_{4}{ }^{-}+e^{-}$

Instead of a simple one-electron reversible process and the ion-pair formation, it can be considered as follows.

$\mathrm{Fc} \rightleftharpoons \mathrm{Fc}^{+}+e^{-}$

$\mathrm{Fc}^{+}+\mathrm{ClO}_{4}^{-} \rightleftharpoons \mathrm{Fc}^{+} \cdot \mathrm{ClO}_{4}^{-}$

The relevant electrochemical data of Fc and its derivatives were listed in Table 1. One clear trend was seen in Table 1 and Fig.1, the $E^{0^{\prime}}$ of $\mathrm{Fc}$ (within $\left.\mathrm{ClO}_{4}^{-}\right)(0.153 \mathrm{~V}$ in Fig. 1A(b)) shifted $30 \mathrm{mV}$ cathodically compared with Fc $(0.183 \mathrm{~V}$ in Fig. 1A(a)). It was attributed to the ion-pairing effect of $\mathrm{Fc}^{+} \cdot \mathrm{ClO}_{4}{ }^{-}$. The formation of ion pair $\left(\mathrm{Fc}^{+} \cdot \mathrm{ClO}_{4}^{-}\right)$was beneficial to the equilibrium shift from $\mathrm{Fc}$ to $\mathrm{Fc}^{+}$(eq.(2)). It facilitated the oxidation of Fc.

Fc- $\mathrm{NH}_{2}$ was employed as ferrocene derivative with strong electron-donating substituent. Inspection of Fig.1A and Table 1 revealed that the $\mathrm{E}^{0^{\prime}}$ of $\mathrm{Fc}-\mathrm{NH}_{2}(-0.159$ V in Fig. 1A(c)) shifted $342 \mathrm{mV}$ negatively compared with Fc (0.183 V in Fig. 1A(a)), 
owing to electron-donating substituent effect. It promoted the negative shift of $\mathrm{E}^{0^{\prime}}$ for ferrocene derivatives and was conducive to the oxidation of $\mathrm{Fc}-\mathrm{NH}_{2}$. It was interpreted as the following factor: the electron-donating substituent resulted in the increase of electron density on iron atom and the energies of HOMO (Highest Occupied Molecular Orbital).

With the addition of TEAP, the $\mathrm{E}^{0^{\prime}}$ of $\mathrm{Fc}-\mathrm{NH}_{2}$ (within $\left.\mathrm{ClO}_{4}^{-}\right)(-0.195 \mathrm{~V}$ in Fig. 1A(d)) shifted $378 \mathrm{mV}$ cathodically compared with Fc (0.183 V in Fig. 1A(a)). The more negative shift for the $\mathrm{E}^{0^{\prime}}$ of $\mathrm{Fc}-\mathrm{NH}_{2}$ (Fig. 1A(d)) reflected two effects: ion-pairing effect and electron-donating substituent effect. Both ion-pairing effect and electron-donating substituent effect facilitated the negative shift of $\mathrm{E}^{0^{\prime}}$ for $\mathrm{Fc}-\mathrm{NH}_{2}$. In addition, the negative shift (Fig. 1A(d)) was more than that two superimposition effect $(378 \mathrm{mV}>30 \mathrm{mV}+342 \mathrm{mV})$. The result showed the positive cooperativity between ion-pairing effect and electron-donating substituent effect.

Analogously, the $\mathrm{E}^{0^{\prime}}$ of $\mathrm{Fc}$ (within $\left.\mathrm{ClO}_{4}{ }^{-}\right)(0.153 \mathrm{~V}$ in Fig. $1 \mathrm{~B}(\mathrm{~b}))$ shifted $30 \mathrm{mV}$ cathodically compared with Fc $(0.183 \mathrm{~V}$ in Fig. $1 \mathrm{~B}(\mathrm{a}))$. For ferrocene derivative with weak electron-donating substituent, the $\mathrm{E}^{0^{\prime}}$ of $\mathrm{Fc}-\mathrm{CH}_{2} \mathrm{OH}(0.192 \mathrm{~V}$ in Fig. $1 \mathrm{~B}(\mathrm{c}))$ showed a negligible positively shift of $9 \mathrm{mV}$ compared with Fc (0.183 V in Fig. 1B(a)) on account of the combined effects including weak hyperconjugation effect and steric hindrance of $-\mathrm{CH}_{2} \mathrm{OH}$. While the $\mathrm{E}^{\mathrm{O}^{\prime}}$ of $\mathrm{Fc}-\mathrm{CH}_{2} \mathrm{OH}$ (within $\left.\mathrm{ClO}_{4}{ }^{-}\right)(0.155 \mathrm{~V}$ in Fig. 1B(d)) shifted $28 \mathrm{mV}$ negatively compared with $\mathrm{Fc}(0.183 \mathrm{~V}$ in Fig. 1B(a)). The negative shift for the $\mathrm{E}^{0^{\prime}}$ of $\mathrm{Fc}-\mathrm{CH}_{2} \mathrm{OH}$ also reflected the positive cooperativity (28 $\mathrm{mV}>30 \mathrm{mV}-9 \mathrm{mV}$ ). Thus it can be seen that the positive cooperativity was 
available, regardless of strong and weak electron-donating substituent.

Moreover, the $\Delta \mathrm{E}_{\mathrm{p}}$ (peak-to-peak potential separation) of $\mathrm{Fc}-\mathrm{NH}_{2}$ decreased from 113 (Fig. 1A(c)) to $85 \mathrm{mV}$ (Fig. 1A(d)), showing the faster electron-transfer kinetics between $\mathrm{Fc}-\mathrm{NH}_{2}$ and electrode in the presence of $\mathrm{ClO}_{4}{ }^{-}$. The present positive cooperativity and decreased $\Delta \mathrm{E}_{\mathrm{p}}$ indicated the significance of ion-pairing studies based on electron-donating substituent.

Taking Fc- $\mathrm{NH}_{2}$ as an example, Fig. 2 showed the $\mathrm{CVs}$ at different scan rates. It was evident that the CVs still remained well-shaped and reversible redox peaks in the range from 50 to $300 \mathrm{mV} \mathrm{s}^{-1}$. Moreover, peak current increased with the increase of the scan rates, while the $\mathrm{E}^{0^{\prime}}$ of $\mathrm{Fc}-\mathrm{NH}_{2}$ (within $\mathrm{ClO}_{4}^{-}$) remained nearly unchanged. It exhibited reversible electrochemical redox for ferrocenyl compounds. Inset of Fig. 2 showed a linear relation between $I_{p a}$ and the square root of the scan rate $\left(v^{1 / 2}\right)$ in $\mathrm{Fc}-\mathrm{NH}_{2}$. The linear relationship suggested that the reaction was a diffusion-controlled process.

\subsection{Ion-pairing effect based on electron-withdrawing substituent}

In contrast, bromoferrocene (described as $\mathrm{Fc}-\mathrm{Br}$ ) and ferrocenecarboxaldehyde (described as $\mathrm{Fc}-\mathrm{CHO}$ ) were employed for studying the ion-pairing based on electron-withdrawing substituent of ferrocene derivatives. Fig. 3 showed CVs of Fc and its derivatives in the presence or absence of $\mathrm{ClO}_{4}{ }^{-}$in solution. As follows in Table 2, the $\mathrm{E}^{0^{\prime}}$ of $\mathrm{Fc}$ (within $\left.\mathrm{ClO}_{4}{ }^{-}\right)(0.153 \mathrm{~V}$ in Fig. $3 \mathrm{~A}(\mathrm{~b}))$ shifted $30 \mathrm{mV}$ negatively compared with Fc $(0.183 \mathrm{~V}$ in Fig. $3 \mathrm{~A}(\mathrm{a}))$ after adding TEAP. This explanation had 
been elaborated above. Introducing electron-withdrawing substituent, the $\mathrm{E}^{0^{\prime}}$ of $\mathrm{Fc}-\mathrm{Br}$ (0.355 V in Fig. 3A(c)) shifted $172 \mathrm{mV}$ positively compared with $\mathrm{Fc}(0.183 \mathrm{~V}$ in Fig. 3A(a)). The reason was that the electron-withdrawing substituent increased positive charge of iron atoms and reduced the energies of HOMO, so it was unfavourable for the oxidation of Fc derivatives [27].

The addition of TEAP and ferrocene derivative with electron-withdrawing substituent, the $\mathrm{E}^{0^{\prime}}$ of $\mathrm{Fc}-\mathrm{Br}$ (within $\left.\mathrm{ClO}_{4}{ }^{-}\right)(0.333 \mathrm{~V}$ in Fig. $3 \mathrm{~A}(\mathrm{~d}))$ shifted $150 \mathrm{mV}$ positively compared with $\mathrm{Fc}(0.183 \mathrm{~V}$ in Fig. $3 \mathrm{~A}(\mathrm{a}))$. The less positive shift of $\mathrm{Fc}-\mathrm{Br}$ (150 $\mathrm{mV}<172 \mathrm{mV}$ ) was due to the ion pairing effect based on the electron-withdrawing substituent. The ion pairing effect resulted in the negative shift of the $\mathrm{E}^{0^{\prime}}$ for $\mathrm{Fc}-\mathrm{Br}$, which was opposite to the electron-withdrawing substituent effect, showing the negative cooperativity.

Similarly for Fc-CHO, the $\mathrm{E}^{0^{\prime}}$ of Fc-CHO (0.486 V in Fig. 3B(c)) shifted $303 \mathrm{mV}$ positively compared with $\mathrm{Fc}(0.183 \mathrm{~V}$ in Fig. $3 \mathrm{~B}(\mathrm{a}))$. While the $\mathrm{E}^{0^{\prime}}$ of $\mathrm{Fc}-\mathrm{CHO}$ (within $\left.\mathrm{ClO}_{4}{ }^{-}\right)(0.454 \mathrm{~V}$ in Fig. 3B(d)) shifted $271 \mathrm{mV}$ positively compared with Fc $(0.183 \mathrm{~V}$ in Fig. 3B(a)). It also showed negative cooperativity between ion-pairing effect and electron-withdrawing substituent effect.

In this system, although the ion pair was introduced, the $\mathrm{E}^{0^{\prime}}$ of $\mathrm{Fc}-\mathrm{Br}$ (within $\mathrm{ClO}_{4}{ }^{-}$) $(0.333 \mathrm{~V}$ in Fig. $3 \mathrm{~A}(\mathrm{~d}))$ and $\mathrm{Fc}-\mathrm{CHO}\left(\right.$ within $\left.\mathrm{ClO}_{4}{ }^{-}\right)(0.454 \mathrm{~V}$ in Fig. 3B(d)) were still more positive than the $\mathrm{Fc}(0.183 \mathrm{~V}$ in Fig. 3A(a)). It indicated that the electron-withdrawing substituent effect was far stronger than ion-pairing effect. Furthermore, the extent of positive shift was gradually increased with the enhanced 
electron-withdrawing effect $(\mathrm{Fc}-\mathrm{CHO}>\mathrm{Fc}-\mathrm{Br})$.

\subsection{Reversal phenomenon of weak electron-withdrawing substituent on electrochemical behaviour}

In the above-mentioned experiments, we studied ion-pairing effect based on electron-donating and electron-withdrawing substituents of ferrocene derivatives, respectively. The results showed that ion-pairing effect exerted an influence on electrochemical behavior of ferrocene derivatives, showing positive and negative cooperativity, respectively. In the negative cooperativity, when ion-pairing effect was stronger than the weak electron-withdrawing substituent effect, reversal phenomenon of the ferrocene derivatives was observed. Hence, vinyl ferrocene (described as $\mathrm{Fc}-\mathrm{CH}=\mathrm{CH}_{2}$ ) was selected as ferrocene derivative with weak electron-withdrawing substituent to explore the reversal phenomenon.

As a demonstration, Fig. 4 clearly showed that the $\mathrm{E}^{0^{\prime}}$ of $\mathrm{Fc}-\mathrm{CH}=\mathrm{CH}_{2}(0.198 \mathrm{~V}$ in Fig. 4(b)) shifted $15 \mathrm{mV}$ positively in contrast to $\mathrm{Fc}(0.183 \mathrm{~V}$ in Fig. 4(a)) on account of weak electron-withdrawing substituent effect. While the $\mathrm{E}^{0^{\prime}}$ of $\mathrm{Fc}-\mathrm{CH}=\mathrm{CH}_{2}$ (within $\left.\mathrm{ClO}_{4}{ }^{-}\right)(0.173 \mathrm{~V}$ in Fig. 4(c)) shifted $10 \mathrm{mV}$ negatively in contrast to Fc $(0.183$ $\mathrm{V}$ in Fig. 4(a)) because of ion-pairing effect. It was different from the strong electron-withdrawing substituents. In this case, ion-pairing effect was stronger than the weak electron-withdrawing substituent effect, so the $\mathrm{E}^{0^{\prime}}$ of $\mathrm{Fc}-\mathrm{CH}=\mathrm{CH}_{2}$ (within $\mathrm{ClO}_{4}{ }^{-}$) was more negative than the $\mathrm{E}^{0^{\prime}}$ of $\mathrm{Fc}$.

Different concentrations of counter anions (within $\mathrm{ClO}_{4}{ }^{-}$) lead to the variations of 
the observed $\mathrm{E}^{0^{\prime}}$ [22] and the reversal phenomenon without exception. Fig. 5 showed $\mathrm{CVs}$ of $\mathrm{Fc}-\mathrm{CH}=\mathrm{CH}_{2}$ at different concentrations of $\mathrm{ClO}_{4}{ }^{-}$, respectively. The negative shift of anodic peak potential became more obvious with the increase of concentration. The linear regression equation was expressed by $E_{\mathrm{pa}}=0.200(\mathrm{~V})-0.0198 \log \left[\mathrm{ClO}_{4}{ }^{-}\right]$ (inset of Fig. 5). In the range from 0 to $0.02 \mathrm{M}$, slightly negative shift of anodic peak potential occured and reversal phenomenon was not observed. It was explained that the ion-pairing effect was weak in the range of low concentration and not enough to offset electron-withdrawing effect. With the increase of $\mathrm{ClO}_{4}{ }^{-}$concentration (from 0.02 to $0.13 \mathrm{M}$ ), the reversal phenomenon became more and more obvious. All these results demonstrated that ion-pairing effect played a significant influence on electrochemical behavior of ferrocene derivatives.

\section{Conclusion}

This work investigated the ion-pairing effect based on the electron-donating and electron-withdrawing substituents effect, respectively. The shift of $\mathrm{E}^{0^{\prime}}$ for ferrocene derivatives was used to estimate the positive cooperativity and negative cooperativity between ion-pairing effect and substituent effect, respectively. The formation of ion pair caused the negative shift of $\mathrm{E}^{0^{\prime}}$ for ferrocene derivatives. It attributed to the fact that the formation of ion pair $\left(\mathrm{Fc}^{+} \cdot \mathrm{ClO}_{4}{ }^{-}\right)$promoted the equilibrium to move towards the oxidation of Fc. It benefited the oxidation of Fc. Both ion pairing effect and electron-donating effect facilitated the negative shift of $E^{0^{\prime}}$ for ferrocene derivatives, showing the positive cooperativity. While electron-withdrawing substituent effect 
resulted in the positive shift of $E^{0^{\prime}}$ for ferrocene derivatives, which was opposite to the ion pairing effect, reflecting the negative cooperativity with ion-pairing effect. Besides, the reversal phenomenon was observed when ion-pairing effect was far stronger than weak electron-withdrawing substituent effect. This work will attract more attention to the significant aspect of ion-pairing effect on electrochemical behavior of ferrocene derivatives and the beyond.

\section{Acknowledgements}

We gratefully acknowledge the financial support from the National Science Foundation of China (Project 21173023, 21174019) and the National 111 Project (B07012) of China. 


\section{References}

[1] J.E. Gorton, H.L. Lentzner, W.E. Watts, Tetrahedron 27 (1971) 4353-4360.

[2] V. Rapic, I. Tabakovic, B. Skundric, M. Lacan, Croat. Chem. Acta. 51 (1978) 333-338.

[3] A.G. Nagy, S. Toma, J. Organomet. Chem. 266 (1984) 257-268.

[4] K. Stahl, G. Boche, W. Massa, J. Organomet. Chem. 277 (1984) 113-125.

[5] W.E. Britton, R. Kashyap, M. El-Hashash, M. El-Kady, M. Herberhold, J. Organomet. Chem. 5 (1986) 1029-1031.

[6] A.A.O. Sarhan, M.S. Ibrahim, M.M. Kamal, K. Mitobe, T. Izumi, Monatsh. Chem. 140 (2009) 315-323.

[7] W.A. Amer, L. Wang, A.M. Amin, L. Ma, H.J. Yu, J. Inorg. Organomet. Polym. Mater. 20 (2010) 605-615.

[8] Y. Zhao, Y. Ding, J. Song, G. Li, G.B. Dong, J.B. Goodenough, G.H. Yu, Angew. Chem. Int. Ed. 53 (2014) 11036-11040.

[9] A. Matei, C. Constantinescu, V. Ion, B. Mitu, I. Ionita, M. Dinescu, C. Vasiliu, A. Emandi, J. Organomet. Chem. 751 (2014) 638-643.

[10] D.R. van Staveren, N. Metzler-Nolte, Chem. Rev. 104 (2004) 5931-5986.

[11] K.E. Dombrowski, W. Baldwin, J.E. Sheats, J. Organomet. Chem. 302 (1986) 281-306.

[12] L.S. Fan, Q.X. Zhang, K.K. Wang, F.H. Li, L. Niu, J. Mater. Chem. 22 (2012) 6165-6170.

[13] M. D. Ward, Chem. Soc. Rev. 24 (1995) 121-134. 
[14] S. Takenaka, Y. Uto, H. Kondo, T. Ihara, M. Takagi, Anal. Biochem. 218(1994) 436-443.

[15] T. Ihara, Y. Maruo, S. Takenaka, M. Takagi, Nucleic Acids Res. 24 (1996) 4273-4280.

[16] Y. Uto, H. Kondo, M. Abe, T. Suzuki, S. Takenaka, Anal. Biochem. 250 (1997) $122-124$

[17] E.S. Yang, M.S. Chan , A.C. Wahl, J. Phys. Chem. 84 (1980) 3094-3099.

[18] J.T. Hupp, Inorg. Chem. 29 (1990) 5010-5012.

[19] G.K. Rowe, S.E. Creager, Langmuir 7 (1991) 2307-2312.

[20] G. Inzelt, L. Szabo, Electrochim Acta. 31 (1986) 1381-1387.

[21] G. Valincius, G. Niaura, B. Kazakevičienè, Z. Talaikytė, M. Kažemėkaitè, E. Butkus, V. Razumas, Langmuir 20 (2004) 6631-6638.

[22] K. Uosaki, Y. Sato, H. Kita, Langmuir 7 (1991) 1510-1514.

[23] T. Kondo, M. Okamura, K. Uosaki, J. Organomet. Chem. 637-639 (2001) 841-844.

[24] D.B. Xiang, G.T. Gao, H.B. Shao, H.L. Li, H-L. Zhang, H-Z. Yu, J. Phys. Chem. C. 114 (2010) 617-621.

[25] D.B. Xiang, N. Merbouh, H.B. Shao, H-Z. Yu, Electrochim Acta. 56 (2011) 5788-5793.

[26] D.B. Xiang, H.B. Shao, Chin. Chem. Lett. 25 (2014) 1379-1381.

[27] E. Coutouli-Argyropoulou, C. Sideris, G. Kokkinidis, J. Organomet. Chem. 691 (2006) 3909-3918. 


\section{Figure Captions:}

Fig.1. (A) CVs of $1 \mathrm{mM} \mathrm{Fc} \mathrm{(a(-)),} 1 \mathrm{mM} \mathrm{Fc}$ and $0.1 \mathrm{M}$ TEAP $(\mathrm{b}(---)), 1 \mathrm{mM}$ Fc-NH $\mathrm{NH}_{2}(\mathrm{c}(-\cdot-)), 1 \mathrm{mM} \mathrm{Fc}-\mathrm{NH}_{2}$ and $0.1 \mathrm{M}$ TEAP $(\mathrm{d}(\cdots \cdots \cdot \cdots))$. (B) CVs of $1 \mathrm{mM} \mathrm{Fc}$ $(\mathrm{a}(-)), 1 \mathrm{mM} \mathrm{Fc}$ and $0.1 \mathrm{M} \mathrm{TEAP}(\mathrm{b}(---)), 1 \mathrm{mM} \mathrm{Fc}-\mathrm{CH}_{2} \mathrm{OH}(\mathrm{c}(-\cdot-)), 1 \mathrm{mM}$ Fc- $\mathrm{CH}_{2} \mathrm{OH}$ and $0.1 \mathrm{M}$ TEAP $(\mathrm{d}(\cdots \cdots \cdots))$. Scan rate was $50 \mathrm{mV} \mathrm{s}^{-1}$.

Fig. 2. CVs of $1 \mathrm{mM} \mathrm{Fc}-\mathrm{NH}_{2}$ containing $0.1 \mathrm{M}$ TEAP at different scan rates: 50, 100, $150,200,300 \mathrm{mV} \mathrm{s}^{-1}$ (from inner to outer), respectively. Inset: the plots of $I_{\mathrm{pa}} v s . v^{1 / 2}$.

Fig. 3. (A) CVs of $1 \mathrm{mM} \mathrm{Fc}(\mathrm{a}(-)), 1 \mathrm{mM} \mathrm{Fc}$ and $0.1 \mathrm{M}$ TEAP $(\mathrm{b}(--\rightarrow)), 1 \mathrm{mM}$ Fc-Br (c(- - - )), $1 \mathrm{mM} \mathrm{Fc-Br}$ and $0.1 \mathrm{M}$ TEAP (d(.......)). (B) CVs of $1 \mathrm{mM} \mathrm{Fc}$ $(\mathrm{a}(-)), 1 \mathrm{mM}$ Fc and $0.1 \mathrm{M}$ TEAP $(\mathrm{b}(--\dashv), 1 \mathrm{mM} \mathrm{Fc-CHO} \mathrm{(c(-} \mathrm{-} \mathrm{-} \mathrm{)),} 1 \mathrm{mM}$ Fc-CHO and 0.1 M TEAP $(\mathrm{d}(\cdots \ldots \ldots))$. Scan rate was $50 \mathrm{mV} \mathrm{s}^{-1}$.

Fig.4. $\mathrm{CVs}$ of $1 \mathrm{mM} \mathrm{Fc}(\mathrm{a}(-)), 1 \mathrm{mM} \mathrm{Fc}-\mathrm{CH}=\mathrm{CH}_{2}(\mathrm{~b}(---)), 1 \mathrm{mM} \mathrm{Fc}-\mathrm{CH}=\mathrm{CH}_{2}$ and $0.1 \mathrm{M}$ TEAP $(\mathrm{c}(-\cdot-))$. Scan rate was $50 \mathrm{mV} \mathrm{s}^{-1}$.

Fig.5. $\mathrm{CVs}$ of $1 \mathrm{mM} \mathrm{Fc}-\mathrm{CH}=\mathrm{CH}_{2}$ and different concentrations of counter anions $\mathrm{ClO}_{4}{ }^{-}$ $0 \mathrm{M}(\mathrm{a}(-)), 0.005 \mathrm{M}(\mathrm{b}(----)), 0.05 \mathrm{M}(\mathrm{c}(-\cdot)), 0.10 \mathrm{M}(\mathrm{d}(\cdots)), 0.13 \mathrm{M}$ $(\mathrm{e}(-\cdot-\cdot))$, respectively. Inset: the plots of $E_{\mathrm{pa}} v s . \log \left[\mathrm{ClO}_{4}^{-}\right]$ 


\section{Table 1}

Electrochemical data based on electron-donating substituent of ferrocene derivatives.

\begin{tabular}{|c|c|c|c|c|c|c|}
\hline Compound & $I_{\mathrm{pa}} / \boldsymbol{\mu A}$ & $\boldsymbol{I}_{\mathrm{pc}} / \boldsymbol{\mu A}$ & $E_{\mathrm{pa}} / \mathbf{V}$ & $E_{\mathrm{pe}} / \mathbf{V}$ & $\Delta E_{\mathrm{p}} / \mathbf{V}$ & $E^{0^{\prime}} / \mathbf{V}$ \\
\hline $\mathrm{Fc}$ & 6.537 & 6.005 & 0.242 & 0.124 & 0.118 & 0.183 \\
\hline $\mathrm{Fc}\left(\mathrm{ClO}_{4}^{-}\right)$ & 5.760 & 6.317 & 0.196 & 0.109 & 0.087 & 0.153 \\
\hline $\mathrm{Fc}-\mathrm{NH}_{2}$ & 4.736 & 4.612 & -0.102 & -0.215 & 0.113 & -0.159 \\
\hline $\mathrm{Fc}-\mathrm{NH}_{2}\left(\mathrm{ClO}_{4}^{-}\right)$ & 4.767 & 4.926 & -0.152 & -0.237 & 0.085 & -0.195 \\
\hline $\mathrm{Fc}-\mathrm{CH}_{2} \mathrm{OH}$ & 4.445 & 4.906 & 0.249 & 0.135 & 0.114 & 0.192 \\
\hline $\mathrm{Fc}-\mathrm{CH}_{2} \mathrm{OH}\left(\mathrm{ClO}_{4}^{-}\right)$ & 4674 & 4.908 & 0.200 & 0.110 & 0.090 & 0.155 \\
\hline
\end{tabular}

$I_{\mathrm{pa}}:$ anodic peak current; $I_{\mathrm{pc}}:$ cathodic peak current; $E_{\mathrm{pa}}:$ anodic peak potential; $E_{\mathrm{pc}}$ : cathodic peak potential; $\Delta E_{\mathrm{p}}$ : peak-to-peak potential separation; $E^{0^{\prime}}$ : formal redox potential. All potentials were reported against the $\mathrm{Ag} \mid \mathrm{Ag}^{+}$.

\section{Table 2}

Electrochemical data based on electron-withdrawing substituent of ferrocene derivatives.

\begin{tabular}{ccccccc}
\hline Compound & $\boldsymbol{I}_{\mathbf{p a}} / \boldsymbol{\mu A}$ & $\boldsymbol{I}_{\mathbf{p c}} / \boldsymbol{\mu A}$ & $\boldsymbol{E}_{\mathbf{p a}} / \mathbf{V}$ & $\boldsymbol{E}_{\mathbf{p c}} / \mathbf{V}$ & $\boldsymbol{\Delta E}_{\mathbf{p}} / \mathbf{V}$ & $\boldsymbol{E}^{\mathbf{0}^{\prime}} / \mathbf{V}$ \\
\hline $\mathrm{Fc}$ & 6.537 & 6.005 & 0.242 & 0.124 & 0.118 & 0.183 \\
$\mathrm{Fc}\left(\mathrm{ClO}_{4}{ }^{-}\right)$ & 5.760 & 6.317 & 0.196 & 0.109 & 0.087 & 0.153 \\
$\mathrm{Fc}-\mathrm{CH}=\mathrm{CH}_{2}$ & 5.912 & 5.953 & 0.254 & 0.141 & 0.113 & 0.198 \\
$\mathrm{Fc}-\mathrm{CH}=\mathrm{CH}_{2}\left(\mathrm{ClO}_{4}^{-}\right)$ & 5.930 & 5.902 & 0.216 & 0.131 & 0.085 & 0.173 \\
$\mathrm{Fc}-\mathrm{Br}$ & 6.013 & 5.738 & 0.414 & 0.296 & 0.118 & 0.355 \\
$\mathrm{Fc}-\mathrm{Br}\left(\mathrm{ClO}_{4}{ }^{-}\right)$ & 5.948 & 6.296 & 0.375 & 0.291 & 0.084 & 0.333 \\
$\mathrm{Fc}-\mathrm{CHO}$ & 5.179 & 5.170 & 0.541 & 0.430 & 0.111 & 0.486 \\
$\mathrm{Fc}-\mathrm{CHO}\left(\mathrm{ClO}_{4}^{-}\right)$ & 5.044 & 5.005 & 0.495 & 0.413 & 0.082 & 0.454 \\
\hline
\end{tabular}

$I_{\mathrm{pa}}:$ anodic peak current; $I_{\mathrm{pc}}$ : cathodic peak current; $E_{\mathrm{pa}}:$ anodic peak potential; $E_{\mathrm{pc}}:$ cathodic peak potential; $\Delta E_{\mathrm{p}}$ : peak-to-peak potential separation; $E^{0^{\prime}}$ : formal redox potential. All potentials were reported against the $\mathrm{Ag} \mid \mathrm{Ag}^{+}$. 
Fig.1

Fig.2

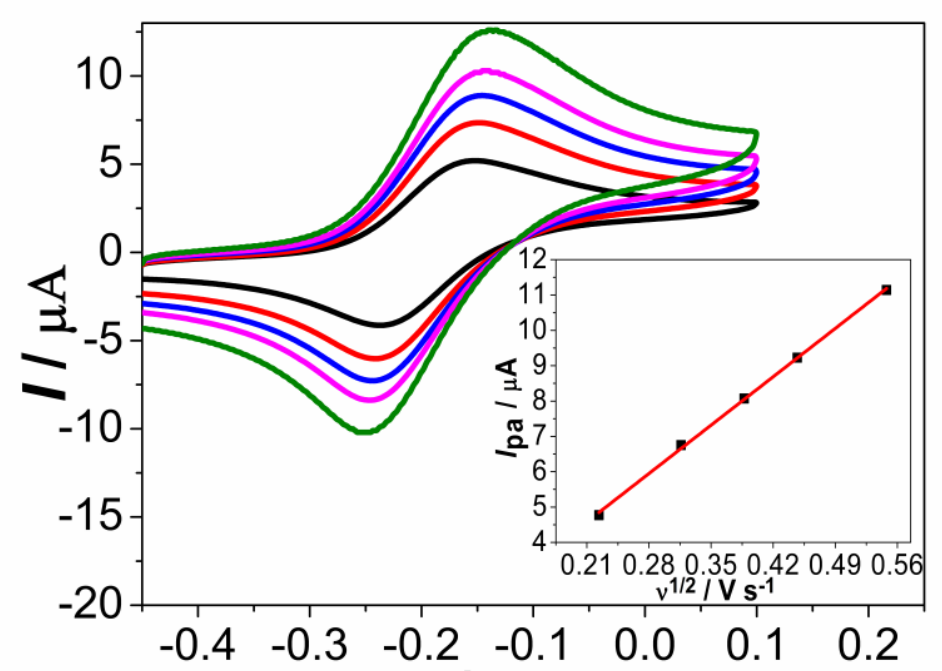

E I V 
Fig.3
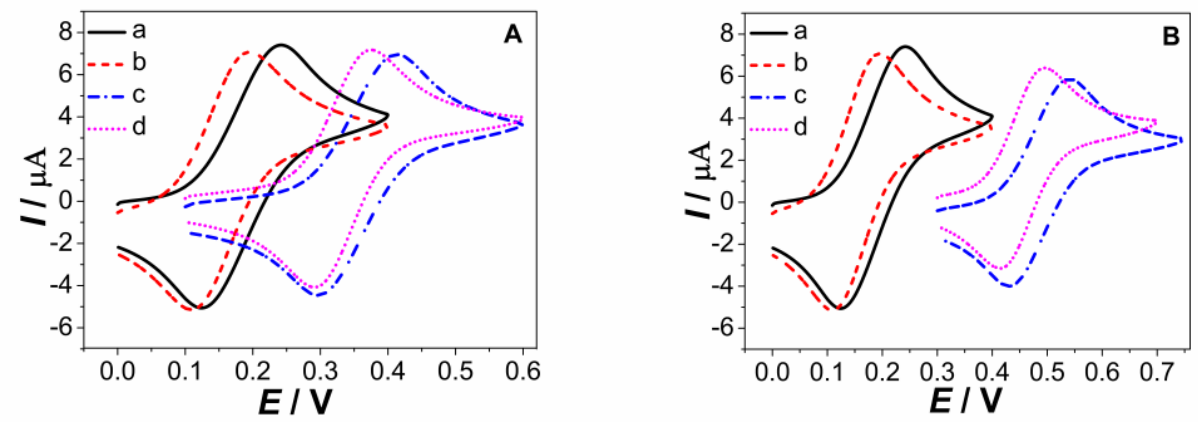
Fig.4

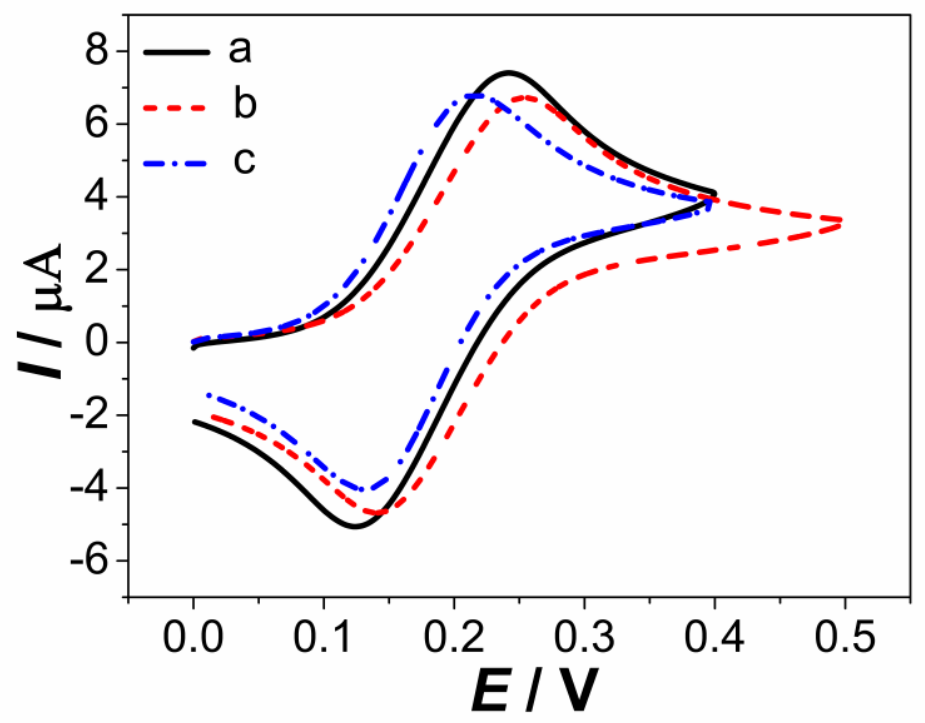


Fig.5

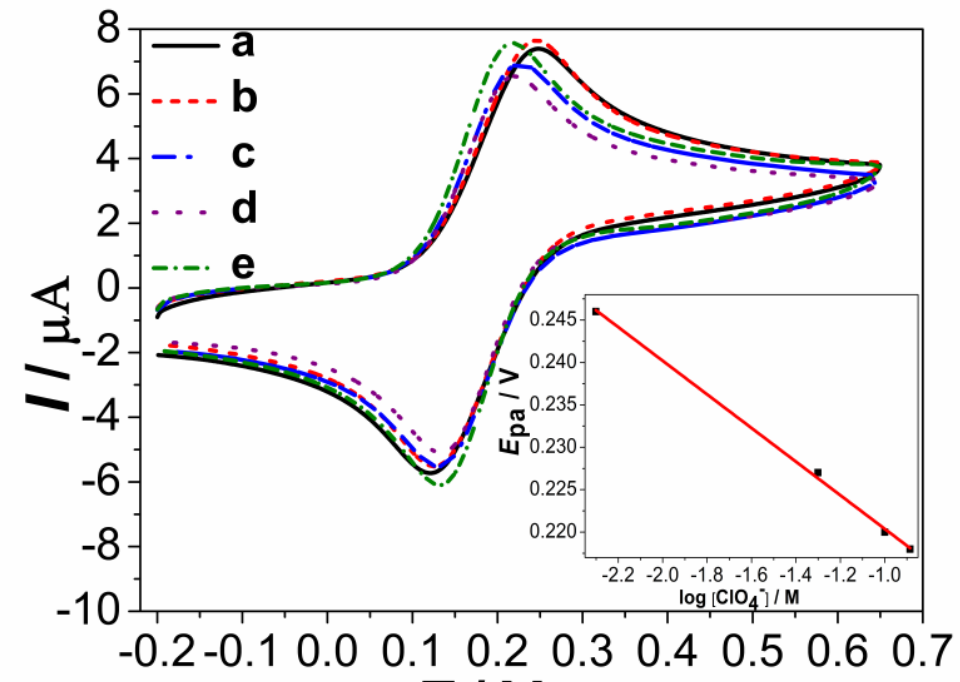

E I V 